MUSICA THEORICA 202011

SCIENTIFIC ARTICLE

Data do recebimento: 07/03/2021

Data da aprovação final: 19/04/2021

\title{
A Fantasia Cromática, BWV 903, de J. S. Bach
}

\author{
Chromatic Fantasy, BWV 903, by J. S. Bach
}

Yara Caznok

Universidade Estadual Paulista Júlio de Mesquita Filho

\begin{abstract}
Resumo: A Fantasia Cromática é considerada um enigma dentro do conjunto das obras de Bach. Única em sua escritura e no nível de virtuosismo técnico exigido para o período em que foi composta, seu caráter livre está em conformidade com o Stylus Fantasticus, próprio das fantasias, tal como descrito por Kircher, Mattheson e C. P. E. Bach. A análise proposta neste texto focaliza o caminho harmônico desse discurso que, por não estar subordinado a materiais temáticos e estruturas formais padronizadas, se apresenta como uma improvisação instrumental, na qual a inventividade do compositor-improvisador realizar-se-ia no momento da execução. As surpreendentes transformações do conteúdo harmônico, raras em outros gêneros musicais barrocos, são, para esta Fantasia, o fundamento para que a persuasão e a eloquência sejam, eficaz e engenhosamente, construídas.
\end{abstract}

Palavras-chave: J. S. Bach. Fantasia. Harmonia. Forma. Stylus Fantasticus.

\begin{abstract}
The Chromatic Fantasy is considered to be one of Bach's most enigmatic works. Unique both in its writing and level of technical virtuosity - considering the period in which it was composed - its free character is in accordance with the Stylus Fantasticus as described by Kircher, Mattheson and C. P. E. Bach. The analysis proposed in this text focuses on the harmonic path of this discourse, which, as it is not subordinated to thematic materials and standardized formal structures, presents itself as an instrumental improvisation in which the inventiveness of the composer-improviser takes place at the time of execution. The surprising transformations of harmonic content, rare in other Baroque musical genres, are, for this Fantasia, the basis for persuasion and eloquence to be effectively and ingeniously constructed.
\end{abstract}

Keywords: J. S. Bach. Fantasia. Harmony. Form. Stylus Fantasticus. 


\section{Fantasia}

O termo designa, desde o Renascimento, uma peça - em princípio instrumental, cujo caráter e estrutura realçam a liberdade de invenção advinda de sua autonomia em relação às palavras. Esta importante característica liberta o compositor da obrigação de pensar temática ou figurativamente sua obra, permitindo-lhe explorar outros parâmetros e elementos musicais que, normalmente, estavam subordinados a unidades identitárias, tais como motivos, temas e/ou sujeitos e estruturas harmônicas e formais padronizadas. Trata-se de música virtuosística que celebra, desde o século XVI, a imaginação e a inventividade do compositorimprovisador, a partir dos atributos sonoros, técnicos e idiomáticos dos instrumentos e cuja finalidade é desafiar e surpreender o ouvinte, apresentando materiais em contínua transformação de tal forma que qualquer previsão ou expectativa que, porventura, tenha sido engendrada, seja contrariada.

Athanasius Kircher, no Livro VII de sua obra Musurgia Universalis, de 1650, um dos mais influentes tratados sobre música do período barroco, descreve oito gêneros de expressão da composição e, dentre eles, o mais livre de todos, o "estilo fantástico" (Stylus Fantasticus), que abriga a Fantasia como uma de suas manifestações.

O estilo fantástico é adequado para instrumentos. Ele é um método de composição muito livre e independente. Por não estar vinculado a um texto nem a um cantus firmus, ele é adequado para demonstrar sua engenhosidade, seu oculto processo harmônico e mostrar o contexto espirituoso de suas cláusulas harmônicas e fugas. É dividido nas formas comumente chamadas de Fantasias, Ricercare, Tocatas e Sonatas $^{1}$ (Kircher 2017 [1650], VII, p. 90).

Outro importante compositor e teórico barroco, Johann Mattheson, em seu livro Der vollkommene Capellmeister (O Mestre de Capela perfeito), de 1739, dá continuidade à descrição de Kircher, detalhando a natureza do estilo fantástico e nomeando procedimentos práticos - composicionais e interpretativos - para sua realização, incluindo, explicitamente, o repertório vocal.

Porque nesse estilo, a maneira de compor, de cantar e de executar é a mais livre, a mais descompromissada que se possa conceber, para que ora se desenvolva uma ideia e em seguida uma outra, pois não está vinculado nem pelo texto nem pela

\footnotetext{
1 "Der fantastische Stil eignet sich für Instrumente. Er ist eine sehr freie und ungebundene Methode des Komponierens. Weil er weder an einen Text noch an ein zugrundeliegendes Thema gebunden ist, ist er geeignet, seinen Einfallsreichtum und sein verborgenes harmonisches Verfahren zu beweisen und den geistreichen Zusammenhang seiner harmonischen Klauseln und Fugen vorzuweisen. Man unterteilt ihn in die Formen, die man gemeinhin Fantasien, Ricercare, Toccaten und Sonaten nennt" (tradução nossa).
} 
melodia, mas sim pela harmonia, de forma que [o estilo] só é perceptível pela habilidade do cantor ou o do executante. Todos os tipos de progressões incomuns, de ornamentos escondidos, de engenhosos volteios e de embelezamentos são criados sem de fato observar o compasso ou a tonalidade não vistos no papel, mas que aparecem; sem engendrar, formalmente, frase principal nem subordinada, sem tema ou sujeito; aqui rápido, e lá hesitante, ora monódico, ora polifônico, e, às vezes, também, um pequeno atraso no compasso, sem grande sonoridade, mas não sem a intenção de agradar, de arrebatar e de provocar deslumbramento. Estas são as principais características do estilo fantástico² (Mattheson 1999 [1739], I, p. $10, \S 93)$.

Embora estudiosos tais como Brewer (2011) e Collins (2005) sinalizem que o sentido do termo fantástico seja diferente em Kircher e em Mattheson, interessa-nos focalizar, em suas descrições, a importância do papel desempenhado pela harmonia, apontada por Mattheson como responsável pela sustentação do discurso musical: pois não se está vinculado nem pelas palavras nem pela melodia, mas sim pela harmonia. Cumpre realçar que essa vinculação harmônica, no entanto, tem características particulares, pois a aventada liberdade composicional se aplica, também, à condução harmônica, da qual se espera inventividade e movimentações inusitadas, por meio de todos os tipos de progressões incomuns, [...] sem a preocupação de observar o compasso ou a tonalidade (Mattheson), para que sejam capazes de revelar [...] o contexto espirituoso de suas cláusulas harmônicas (Kircher).

Inspirada pelas caracterizações de Kircher e de Mattheson a respeito do papel desempenhado pela harmonia em uma Fantasia, nossa proposta de análise da Fantasia Cromática parte em busca desses procedimentos harmônicos próprios e possíveis nesse gênero, procurando entendê-los como constituintes de seu caráter de declamação "espirituosa" e de seu incomum e desafiante percurso auditivo.

\footnotetext{
2 "Denn dieser Styl ist die allerfreieste und ungebundeste Setz- Sing- und Spiel-Art die man nur erdencken kan, da man bald auf diese bald auf jene Einfälle geräth, da man sich weder an Worte noch Melodie, obwohl an Harmonie, bindet, nur damit der Sänger oder Spieler seine Fertigkeit sehen lasse; da allerhand sonst ungewöhnliche Gänge, versteckte Zierrathen, sinnreiche Drehungen und Verbrämungen hervorgebracht werden, ohne eigentliche Beobachtung des Tacts und Tons, unangesehen dieselbe auf dem Papier Platz nehmen; ohne förmlichen Haupt-Statz und Unterwurff, ohne Thema und Subject, das ausgeführet werde; bald hurtig bald zögernd; bald ein- bald vielstimmig; bald auch auf eine kurze Zeit nach dem Tact; ohne Klang-Maasse; doch nicht onhe Absicht zu gefallen, zu übereilen und in Verwunderung zu setzen. Das sind die wesentlichen Abzeichen des fantastischen Styls" (tradução nossa).
} 


\subsection{A Fantasia Cromática e Fuga}

Johann Nikolaus Forkel (1749-1818), considerado fundador da musicologia histórica germânica e primeiro biógrafo de J. S. Bach, dedica o capítulo IX de seu livro Sobre a vida, arte e obra de Johann Sebastian $\mathrm{Bach}^{3}$, de 1802, às composições do mestre. Na seção intitulada "Composições para teclado", Forkel enumera e descreve, rapidamente, oito coleções ou grupos de peças: 1) Seis Pequenos Prelúdios para Iniciantes; 2) Quinze Invenções a duas vozes; 3) Quinze Invenções a três vozes; 4) O Teclado bem Temperado; 5) Fantasia Cromática de Fuga; 6) Uma Fantasia; 7) Seis grandes Suites [Suites Inglesas]; 8 Seis pequenas Suites [Suites Francesas]. Ao comentar a Fantasia Cromática e Fuga, destaca seu caráter único e diferenciado, que a separa das demais obras para teclado.

Realizei infindáveis esforços para encontrar mais uma peça de Bach que fosse desse gênero, mas foi em vão. Esta Fantasia é única e nunca houve nada semelhante a ela. Eu a recebi, primeiramente, de Whil. Friedmann [que me a enviou] de Braunschweig. Um de seus e meus amigos, que gostava de fazer versos com rimas paralelas, escreveu em uma folha anexa:

Como complemento vem

Alguma música de Sebastian

Costumeiramente chamada: Fantasia Cromática

Permanecerá linda por todos os séculos

É estranho que esse trabalho extraordinariamente artístico cause impressão até mesmo no ouvinte mais inexperiente, desde que executado de forma limpa/cuidadosa ${ }^{4}$ (Forkel 2000 [1802], p. 108).

O ano de composição da Fantasia é incerto. Nenhum manuscrito autógrafo foi encontrado e, das inúmeras cópias que circulavam entre os alunos de Bach, vinte e

\footnotetext{
3 "Über Johann Sebastian Bachs Leben, Kunst und Kunstwerk".

4 "Unendliche Mühe habe ich mir gegeben noch ein Stück dieser Art von Bach aufzufinden. Aber vergeblich. Diese Fantasie ist einzig und hat nie ihres Gleichengehabt. Ich erhielt sie zuerst von Wilh. Friedemann aus Braunschweig. Einer seiner und meiner Freunde, der gerne Knittelverse machte, schrieb auf ein beygelegtes Blatt:

Anbey kommt an

Etwas Musik von Sebastian,

Sonst genannt: Fantasia chromatica;

Bleibt schön in alle Saecula.

Sonderbar ist es, daß diese so außerordentlich kunstreiche Arbeit auch auf den allerungeübtesten Zuhörer Eindruck macht, wenn sie nur irgend reinlich vorgetragen wird" (tradução nossa).
} 
cinco foram preservadas. A cópia mais antiga traz a data de 6 de dezembro de 1730, mas pesquisadores creem que Bach poderia tê-la composto uma década antes, por volta de 1720, quando morava em Cöthen e que, mais tarde, em Leipzig, a peça teria sido revista. Schleuning (1969) e Wiemer (1988) apontam a relação entre a composição da Fantasia e a morte de Maria Barbara, a primeira esposa de Johann Sebastian. Voltando a Cöthen, após uma longa viagem a Carlsbad (hoje Karlovy Vary), na qual acompanhou o Príncipe Leopoldo, o compositor encontrou Maria Barbara já sepultada, em julho de 1720. Segundo esses estudiosos, essa grande tristeza pode ter sido a motivação para a criação dessa obra tão especial e única, considerada por muitos como um Lamento, um Tombeau.

Sua primeira publicação aconteceu em 1802, integrando o volume VIII das Obras Completas, pela editora Bureau de Musique, fundada pelos músicos Hoffmeister e Kühnel, em Leipzig.

\section{Análise}

Com apenas 79 compassos, a Fantasia prepara e dialoga com a Fuga em diversos aspectos que se apresentam com contrastes muito agudos, mais do que aqueles normalmente encontrados em Prelúdios ou Tocatas que precedem as Fugas. O contraste que, talvez, salte primeiramente aos ouvidos seja a métrica que, na Fantasia, experimenta uma flutuação que se recusa à submissão do compasso, tal como mencionado por Mattheson. À maneira de uma improvisação, desenvolvem-se figurações atemáticas que ora permitem e ora ocultam a possibilidade de percepção do compasso quaternário que, escrito no início da Fantasia, se mantém até seu fim.

Uma escuta e um olhar mais atentos, entretanto, percebem que, inerentes à métrica, são a harmonia, os gestos e motivos melódicos, e as resultantes formais, compostos de forma una e inseparável, e cujas forças se somam para que o efeito de oscilação entre a estabilidade e a instabilidade do fluxo sonoro se acentue.

Com a entrada da Fuga, um outro mundo se abre: sua suave métrica ternária é enfatizada em sua constância, garantindo a regularidade necessária à austeridade das estruturações contrapontísticas.

O plano geral da Fantasia admite que consideremos suas partes e seções de maneiras ligeiramente diferenciadas, mas o corte mais evidente e com o qual Schulenberg (2006), por exemplo, concorda acontece no compasso 49, quando a 
indicação de Rezitativ, feita por Bach, articula o discurso de maneira inesperada, em duas partes.

\begin{tabular}{|l|l|}
\hline Parte A: c. 1 a 48 & $\begin{array}{l}\text { Parte B: c. } 49 \text { a } 79 \\
\text { Rezitativ }\end{array}$ \\
\hline
\end{tabular}

\subsection{Parte A: compassos 1 a 48}

Essa primeira grande parte tem um caráter de Tocata, ou seja, tem um perfil instrumental virtuosístico para teclado, com três tipos básicos de figurações:

a) Movimentos escalares rápidos em fusas, encontrados nos compassos 1 e 2, e 21 a 25. As características mais proeminentes deste elemento são a direção e a extensão: a velocidade em que as escalas são executadas leva-nos a considerar muito mais a amplitude do movimento e sua direção do que a discriminação de seus elementos internos. Os c. 1 e 2 apresentam a escala de ré menor em suas versões melódica e harmônica.

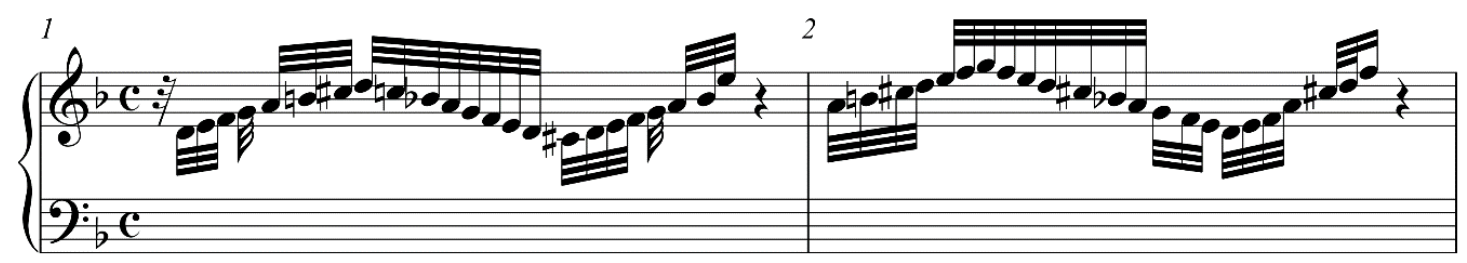

Exemplo 1: Fantasia, c. 1 e 2.

b) Desenhos de tríades arpejadas em semicolcheias que se valem dos graus conjuntos para preenchimento de intervalos e criação de diferentes motivos fugidios que ora são trabalhados como sequência, ora sugerem e/ou realizam uma pseudopolifonia a duas vozes.

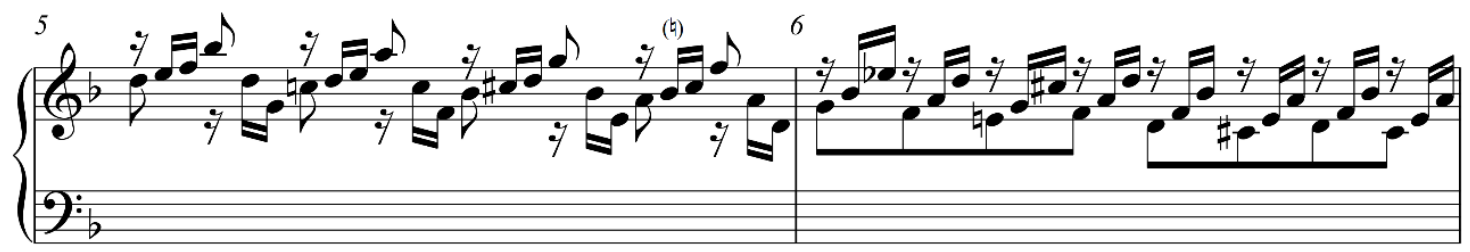

Exemplo 2: Fantasia, c. 5 e 6. 
c) Arpeggi densos com 6 a 8 notas, escritos com valores de mínima e interpretados com certa liberdade de tempo, à maneira dos prelúdios franceses non mesurés do século XVII. A indicação de arpeggio é do compositor e a qualidade destes arpejos é muito diferente daquela dos desenhos arpejados que os precederam (c.3 a 20). Não há, aqui, a formação de motivos que auxiliem o ouvido no desenrolar dos arpejos, que se apresentam como pura movimentação harmônica, livre da figuratividade de um desenho ou padrão rítmicomelódico. Uma frágil direcionalidade pode ser percebida a partir da linha cromática construída pelas notas superiores de cada grupo de arpeggi.

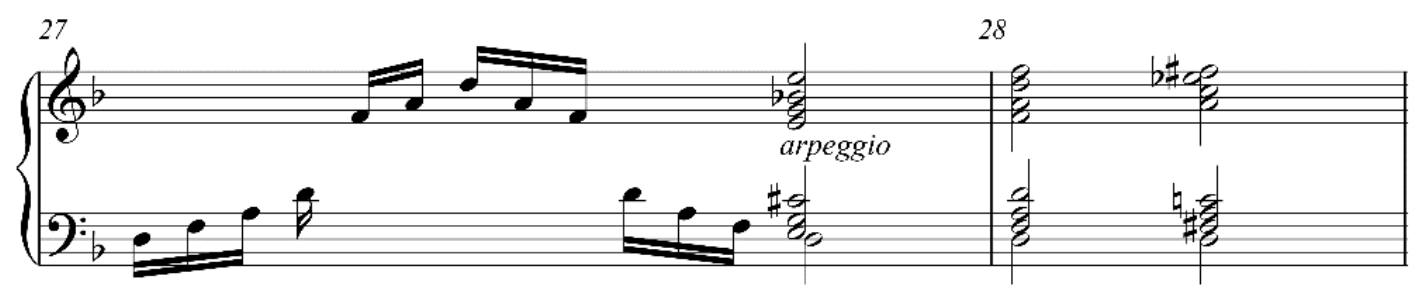

Exemplo 3: Fantasia, c. 27 e 28.

Nesses 48 compassos, duas seções se delineiam - Aa e Ab.

Aa: c. 1 a 26

Escalas e acordes arpejados
Ab: c. 27 a 48

Arpeggi

Esta segmentação binária é perceptível graças à diferenciação textural existente entre as duas seções e à força do fechamento harmônico na tônica ré menor, no c. 27. A chegada em ré menor vinha sendo anunciada desde o c. 18, por meio de desenhos sobre as Dominantes Lá e de dó\# diminuto, com uma primeira resolução no c. 24, $3^{\circ}$ tempo. O c. 25 apresenta o VII diminuto de Lá, que surge em seu formato 6/4 cadencial (ré com 5 $5^{\mathrm{a}}$ no baixo), transformando-se, por meio de um arpejo descendente em tercinas, em ré no seu estado fundamental, na cabeça do c. 27. A partir desse ponto, os grupos de arpeggi se alternam com curtos episódios de desenhos escalares, constituindo-se em uma ideia nova, com força de evento contrastante e levam a uma intensificação de forças que atingem seu clímax no acorde de Dominante - Lá, no c. 49, momento em que começa o Recitativo.

$\mathrm{Em} \mathrm{Aa}$, as vigorosas escalas dos dois primeiros compassos anunciam, de maneira resumida, a movimentação harmônica que regerá os próximos 25 compassos: da Tônica ré para a Dominante Lá, no c. 1, abrindo para uma suspensão, tornada mais 
eloquente graças à pausa que abruptamente interrompe o fluxo ascendente de fusas; da Dominante para a Tônica, c. 2, cadência autêntica que também termina no silêncio de uma pausa.

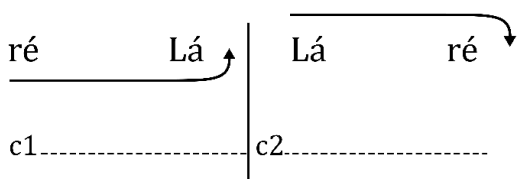

Figura 1: cadências suspensiva e autêntica, c. 1 e 2.

A assertividade dessa abertura, no que se refere às direções e às movimentações harmônicas inequívocas $(t-D / D-t)$, vai começar a ser gradualmente desfeita, a partir do c. 3. A presença da entidade melódica matriz, a escala de ré em suas três formas - natural, melódica e harmônica - e mais sua versão cromática, será ouvida como base de figurações melódico-harmônicas que se desdobram a partir dela, até o c. 11.

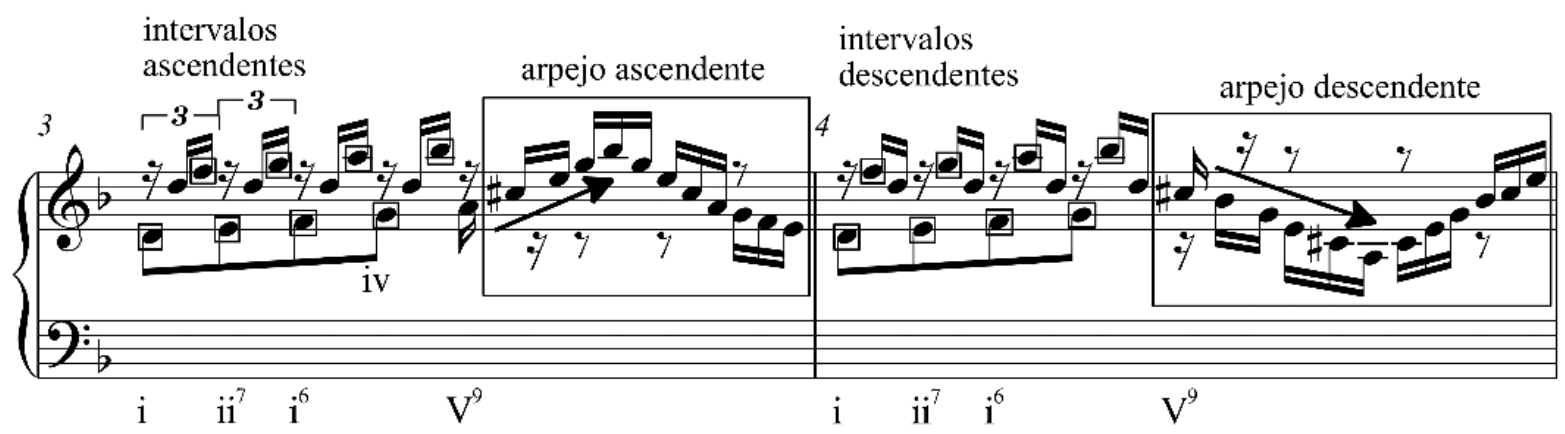

Exemplo 4: Fantasia, c. 3 e 4.

Nos c. 3 e 4, no mesmo registro de oitava, a voz intermediária mantém um pedal em ré e as vozes externas, por aumentação (semicolcheias em tercinas e colcheias), enunciam fragmentos ascendentes da escala. Os primeiros arpejos aparecem nas metades finais desses compassos, resultantes da abertura dos intervalos de $3^{\mathrm{a}}, 4^{\mathrm{a}}, 5^{\mathrm{a}}$ e $6^{\mathrm{a}}$ que se formaram entre a nota pedal e os graus escalares, na mão direita. Nesta micromovimentação percebe-se a relação intrínseca entre escala (grau conjunto), intervalo e acorde/função harmônica: os arpejos são o clímax das ascendências escalares e da aumentação intervalar que, chegando a uma $7^{\text {a }}$ diminuta/2 $2^{\text {a }}$ aumentada (Dó\#-Sib), provocam o arpejamento da função Dominante $\left(\mathrm{D}^{b}\right)$, com mudança de textura e, na segunda metade dos arpejos, com mudança, também, de direção para o fechamento da ideia. O ritmo harmônico realça a chegada 
desses microclímax: depois de quatro colcheias nas quais as funções de Tônica e de Subdominante se alternam, uma mínima garante o desdobramento pleno da Dominante.

Nos próximos compassos, 5 e 6, a escala de ré menor natural inicia sua descendência em lapsos temporais maiores: os quatro primeiros graus aparecem em posição de semínimas e depois os outros se aceleram, em colcheias. Figurações mais onduladas, que equilibram graus conjuntos e intervalos maiores (em tamanho), constroem acordes arpejados, no c. 5, que se sucedem pelo círculo das quintas e cujas direções ascendente/descendente realçam o ritmo harmônico em colcheias, provocando, pela concentração de oito acordes diferentes em um só compasso, uma precipitação na dinâmica do discurso. O c. 6 arrefece a agitação do c. 5 graças à direção uniforme dos intervalos da mão direita e, embora o ritmo harmônico continue em colcheias, os acordes tecem bordaduras em torno da Tônica ré e da Dominante Lá.

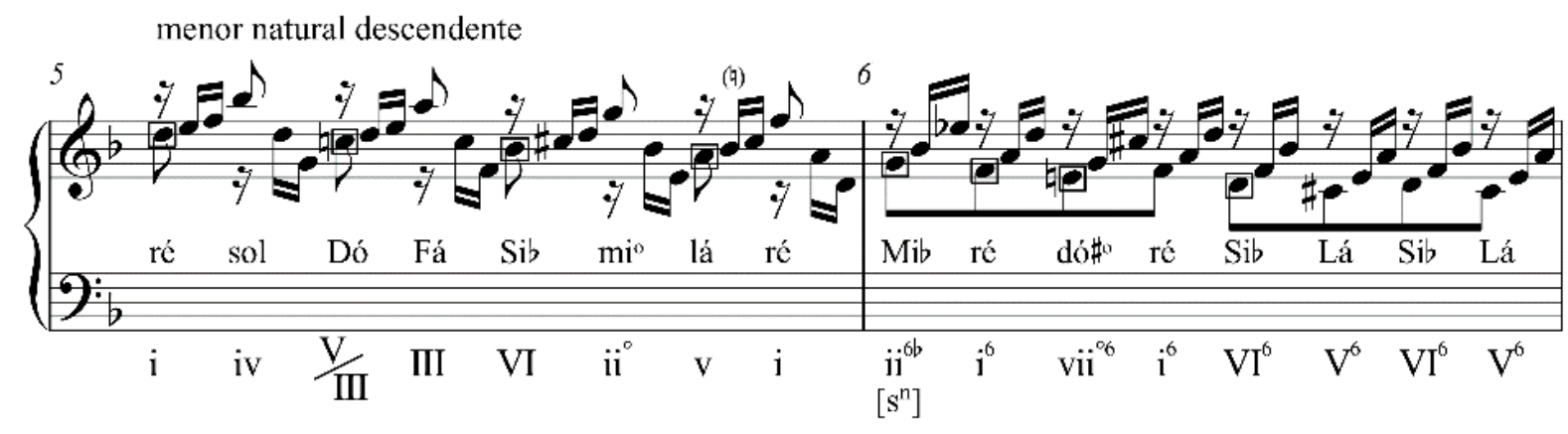

Exemplo 5: Fantasia, c. 5 e 6.

A partir do c. 7, na retomada do movimento descendente da escala de ré, que sofre uma variação pela interferência de intervalos melódicos de terças, fazendo com que os graus da escala sejam enunciados a cada dois tempos, o diatonismo dos acordes formados pelos arabescos da mão direita vai sendo abandonado. São, majoritariamente, acordes de sétima diminuta - Dominantes individuais - que se sucedem e, ao chegar nos c. 10 e 11, o ambiente harmônico está transformado. Aos acordes de sétima diminuta, juntam-se os intervalos de segundas menores da mão esquerda que, percorrendo uma escala cromática, chegam à região mais grave de toda a seção e configuram-se como ponto culminante do movimento descendente iniciado no c. 3. 

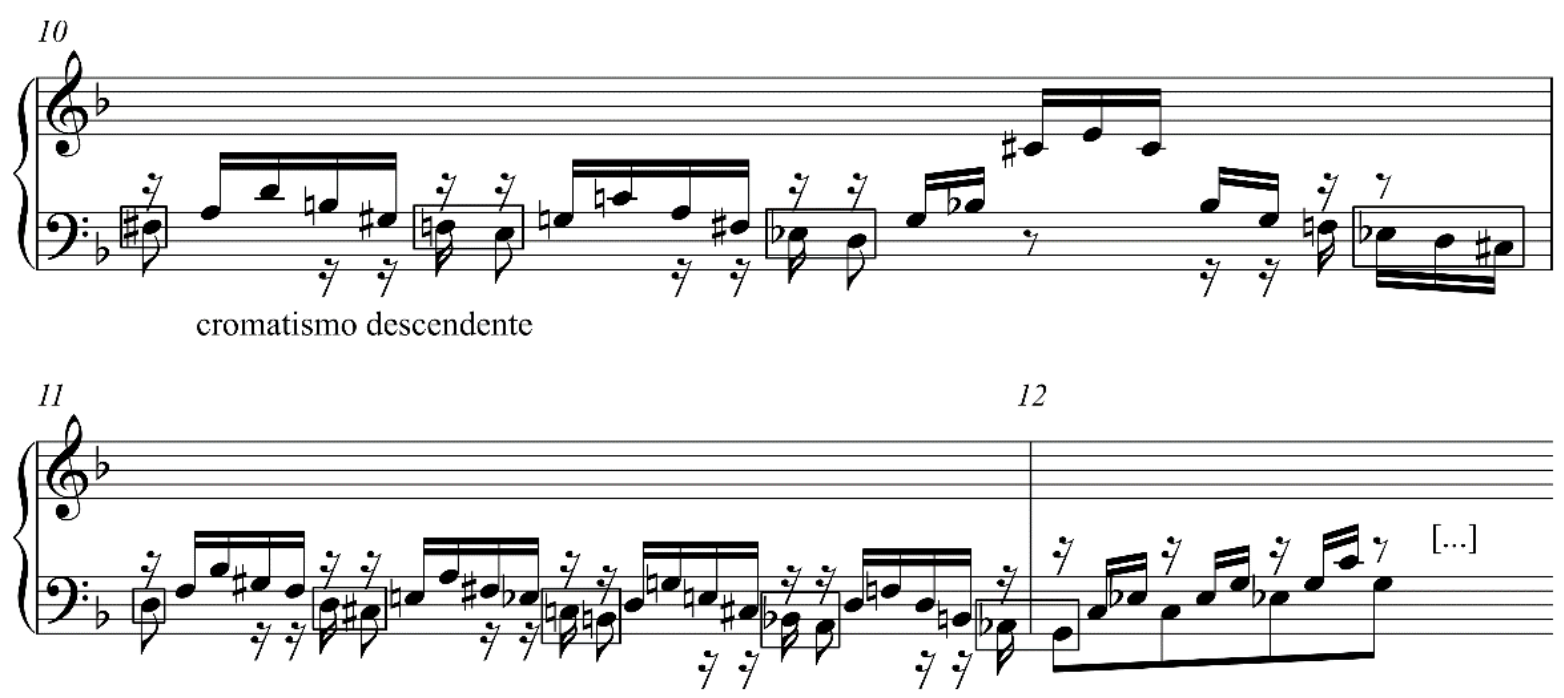

Exemplo 6: Fantasia, c. 10 a 12.

O resumo desses onze compassos nos mostra o caminho de duas linhas conjugadas em suas direcionalidades: a transformação do material diatônico em cromático e a derivação dos intervalos formadores dos acordes a partir dos graus conjuntos da escala. Os c. 1 e 2 contêm escalas diatônicas e nenhum arpejo/acorde e os c. 7 a 11 contêm uma escala cromática e um arpejo/acorde a cada semínima. Percebe-se, também, que a apresentação e confirmação da tonalidade de ré menor se deu a partir dos elementos essenciais e fundantes do idioma tonal: o grau conjunto (escala), que personifica a força melódica, e o arpejo (acorde), que desenvolve a força harmônica. Por não estarem submetidas a um Tema ou a um texto, como já mencionado, essas duas forças se encontram livres, em sua essência, para interações, transformações, permutações e criação de direcionalidades.

Os arpejos que ascendem com rapidez por duas oitavas, no c. 12 confirmam a finalização do movimento descendente e, sobre os acordes de dó e de dó\# diminuto, construídos sobre duas possibilidades de VII grau (natural e harmônico, respectivamente), conduzem-nos a uma situação harmônica mais diatônica, preparando uma articulação: a partir do c. 13, o ritmo harmônico se torna mais tranquilo e resoluções na tônica recuperam a clareza da tonalidade de ré menor; os c. 18 a 20 mantêm o acorde de Lá e finalizam essa subseção (c. 12 a 20) com uma cadência suspensiva, enfatizada pela distância de quatro oitavas entre as últimas notas (fundamentais do acorde) e o mordente sobre a colcheia da mão direita. 


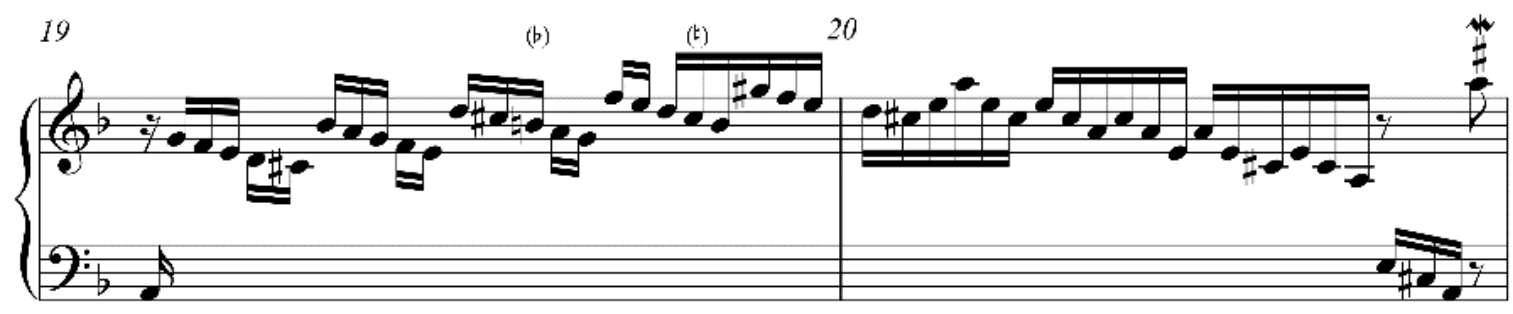

Exemplo 7: Fantasia, c. 19 e 20.

As escalas em fusas que abriram a Fantasia voltam, no c. 21, espraiando-se por cinco compassos e trazendo-nos uma situação que colocaria em dúvida a articulação entre as duas seções, anteriormente mencionada: o reaparecimento do material inicial (c. 1 e 2) poderia ser ouvido tanto como fechamento da primeira unidade (Aa: c. 1 a 26 - opção I), ou como abertura da segunda seção, já que a memória poderia relacionar o gesto escalar como sendo o reinício de uma outra unidade (Ab: c. 21 a 48, opção II).

Opção I: Aa: c. 1 a 26 - Ab: c. 27 a 48

Opção II: Aa: c. 1 a 20 - Ab: c. 21 a 48

Nessa questão, optamos por tomar como critério a situação harmônica, impondo-a sobre a figuração rítmico-melódica: os compassos 18 a 20 insistem, exclusivamente, em desenhos sobre o acorde de Lá, primeira Dominante e, quando encontramos o mordente sobre a colcheia - elemento responsável pela cessação da movimentação - somos levados a relacioná-lo com o gesto cadencial suspensivo do c. 1, de forma expandida e intensificada. Os compassos 21 a 24, com os acordes de mi mi - dó\# - Lá7 (ii - ii $^{\circ}$ - vii ${ }^{\circ}$ - V7), nos levam, finalmente, à resolução em ré (3o tempo do c. 24). Segue-se mais uma cadência, para confirmação, e a tétrade de sol\# diminuto (c. 25), vii ${ }^{\circ}$ grau de Lá, introduz, por meio de arpejos descendentes, a função da Dominante $6 / 4$ cadencial, no c. 26. Sua resolução na tônica ré, no c. 27 , dá início à Seção Ab, e realiza a movimentação harmônica ouvida no c. 2, de forma amplificada.

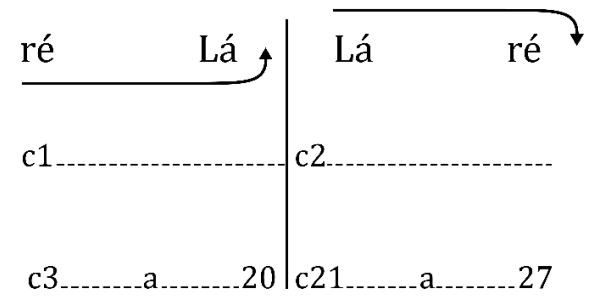

Figura 2: Ampliação dos movimentos cadenciais suspensivo e autêntico dos c. 1 e 2, nos c. 3 a 20 e 21 a 27. 
A partir do compasso $27(\mathrm{Ab})$, seção dos arpeggi, há um progressivo afastamento da estabilidade experimentada em Aa, conduzindo o discurso para uma modesta abertura harmônica, totalmente aderida ao desenrolar dos arpejos e à flutuação métrica. São três segmentos de acordes arpejados, interpolados por figurações de fusas e semicolcheias, respectivamente.

O segmento I tem o menor número de arpejos (6) e sua harmonia confirma as funções principais de ré, assumindo, por isso, uma função expositiva da nova ideia. A ascensão cromática da voz superior também ajuda o ouvido a acompanhar a direcionalidade das últimas duas sensíveis.

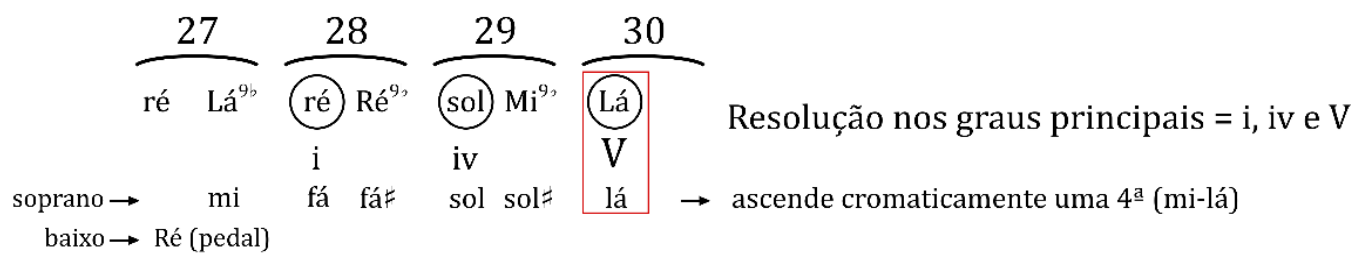

Figura 3: Arpeggi I, c. 27 a 30.

O segmento II, centro desta seção $\mathrm{Ab}$, tem o maior número de arpejos (19) e características claras de um Desenvolvimento. A sensação, até o c. 39 é de instabilidade em termos de direcionalidade harmônica, pois há muitas dominantes individuais que não chegam a nenhuma resolução. Diferentemente do segmento I, os insistentes movimentos arpejados têm na voz superior uma movimentação cromática hesitante e não definida, no tocante à direção: são arpejos livres, sucedendo-se como se fosse uma improvisação guiada pela pura sonoridade de tétrades com intervalos diminutos e cujas funções harmônicas teriam sido momentaneamente abandonadas. Ainda que uma resolução ocorra no c. 36, ela nos leva a uma cadência suspensiva individual sobre a dominante menor, evento que abre ainda mais o caráter vago, de estar à deriva na condução harmônica.

A partir do c. 38, cadências autênticas sobre a tônica (c. 39) e a subdominante napolitana (c. 40) devolvem uma frágil direcionalidade ao discurso para que a cadência de engano, em Sib, adquira mais efeito. 


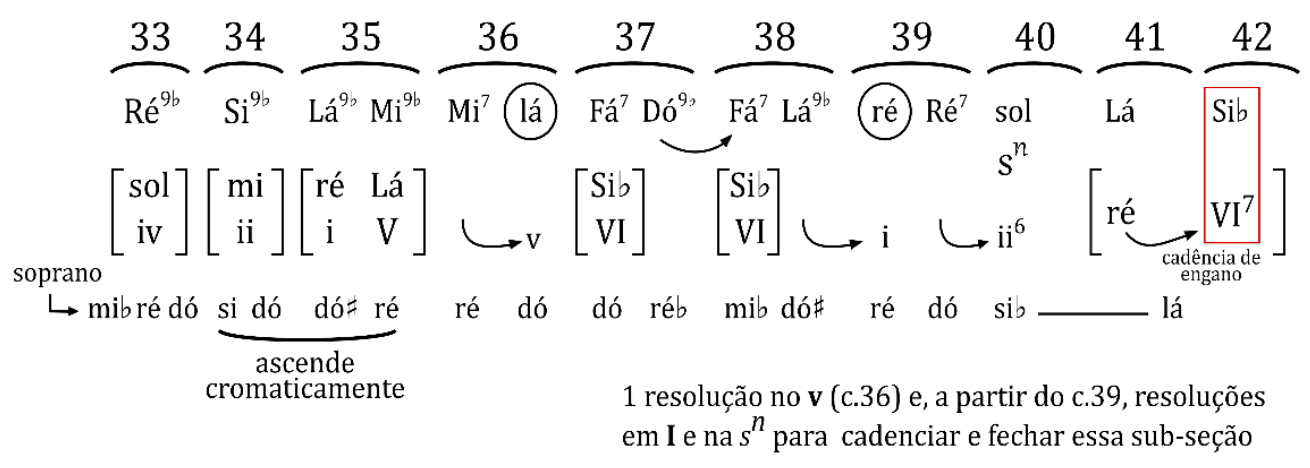

Figura 4: Arpeggi II, c. 33 a 42.

Contrariamente ao que se poderia esperar, o terceiro e último segmento, com 11 arpejos, não se apresenta como fechamento harmônico de $\mathrm{Ab}$ em ré. Seu encerramento é percebido pelo desaparecimento dos materiais e textura característicos (arpeggio e figurações em fusas e semicolcheias) e pela entrada de novas figurações contrastantes, a partir do acorde de Lá, em mínimas, com uma das vozes em semínimas. A harmonia se afasta ainda mais de ré menor, apresentando movimentos cadenciais mais amplos, assentados sobre o círculo das quintas que realçam o V grau - lá (c. 46) e Lá (c. 49). Este acorde abre o Rezitativ de maneira inesperada e com uma tensão acentuada pela apogiatura de $4^{\underline{a}}$ que resolve sobre a $3^{\text {a }}$ do acorde (4⿳亠丷厂 Sus). Esta apogiatura aparecerá de forma recorrente nos compassos seguintes, mostrando-se como motivo gerador de uma escala cromática descendente (vide Exemplo 9).

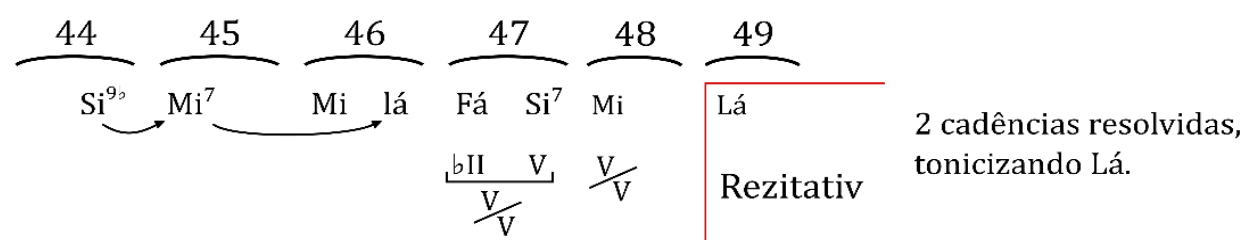

Figura 5: Arpeggi III, c. 44 a 49.

\subsection{Parte B, c. 49 a 79}

Três sub-seções podem ser identificadas nesses trinta e um compassos:

a) Rezitativ: c. 49 a 61;

b) retorno das figurações escalares (Tocata) e dos desenhos do Rezitativ: c. 62 a 74;

c) Peroratio ou Coda: c. 75 a 79. 
O coração da Fantasia, o Rezitativ, com seus treze compassos (c. 49 a 61), é objeto de análise de importantes estudiosos, tais como Schleuning (1969) e Schulenberg (2006), que buscam compreender, sobretudo, a estrutura harmônica que sustenta esses poucos compassos tão desafiadores.

A referência à música vocal pode ser percebida se observarmos os acordes da mão esquerda, que, à maneira de um recitativo secco, apenas pontuam a mão direita solista. Esta, aproxima-se mais de uma cadenza do que de um recitativo - normalmente silábico - pois seus desenhos têm feição de coloratura, de melismas improvisados.
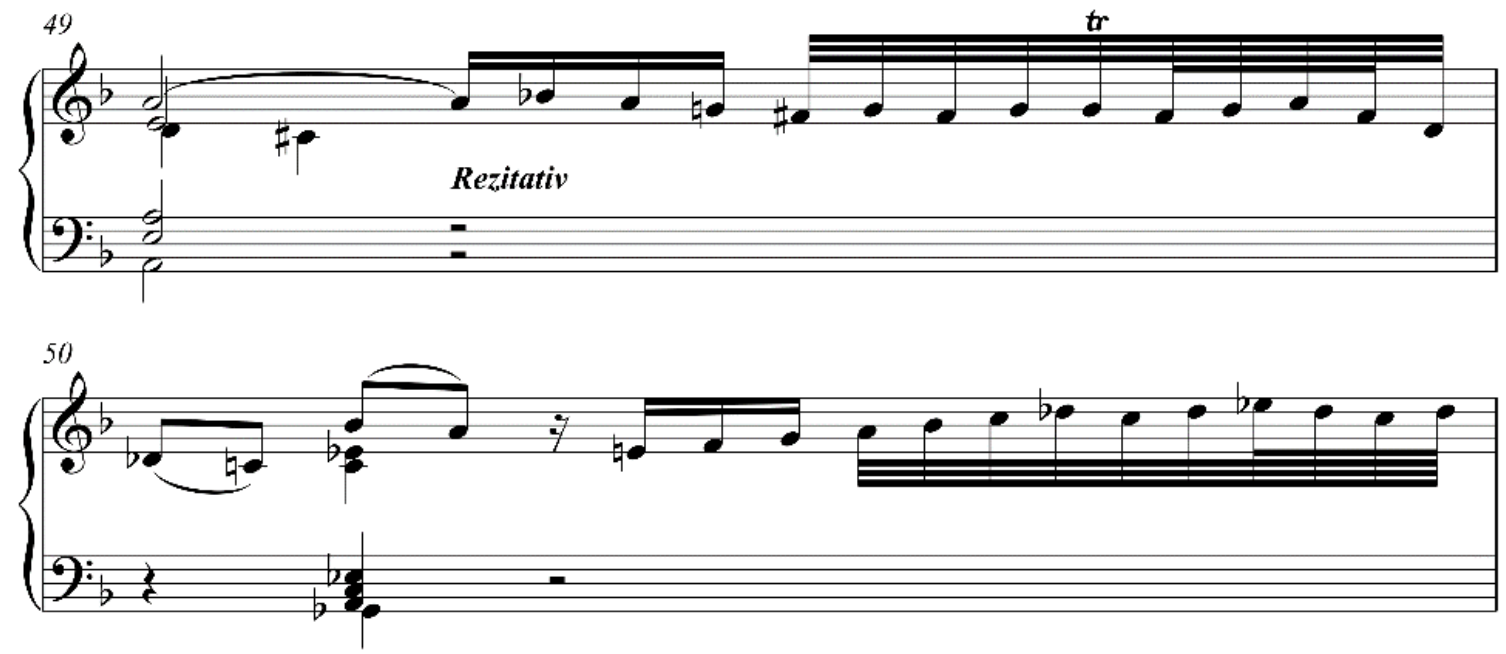

Exemplo 8: entrada do Rezitativ, c. 49 e 50.

Os elementos que compõem o solo do Rezitativ podem ser discriminados em duas figurações distintas: I) melismas compostos por valores muito curtos e com ornamentos escritos ou cifrados, e cuja indefinição de direção e de métrica acentuam o caráter de improvisação. Embora muito próximos em sua identidade fugidia, os desenhos não se sucedem por iteração ou derivação, com exceção das bordaduras em 6as paralelas dos c. 52 e 53, momento este nomeado de Arioso por Schleuning (1969, p. 69); II) motivo melódico de segundas descendentes - apogiaturas majoritariamente menores, prenunciado pela resolução, em semínimas, da $4^{a}$ Sus, no c. 49. A importância desse motivo de segundas descendentes está relacionada à declamação dos desenhos melismáticos livres, cumprindo a função de emoldurá-los em pequenas unidades de sentido de diferentes tamanhos e perfis. Simultâneos ou antecipando-se aos acordes da mão esquerda, que os realçam, a maior parte dos motivos de segundas são pronunciados em valores de colcheia, destacando-se do fluxo e pontuando as imprevisíveis ondulações melódicas. Uma lenta descendência 
cromática pode ser "costurada”, se unirmos as apogiaturas Sib-Lá (c.52), Láb-Sol (c.56) e Fá\#-Mi\# (c. 59).

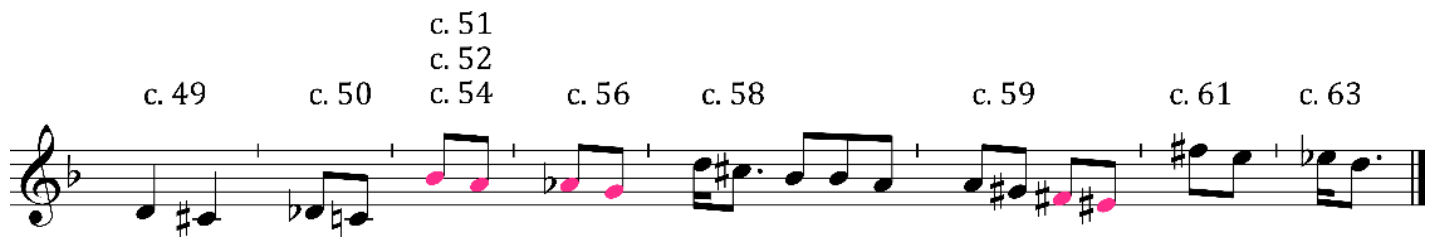

Exemplo 9: Rezitativ, resumo dos motivos de segunda descendente, c. 49 a 63.

Essa liberdade experimentada pela linha melódica solista - mais "fácil" de ser assimilada pelo ouvido pois as práticas da diminuição e da ornamentação já nos habituaram a prescindir de referências métricas e a usufruir das flutuações melódicas - é radicalizada na dimensão harmônica. É nesta curta seção que o conceito de imaginação fantástica, de engenhosidade na arte de surpreender o ouvinte se realiza plenamente. Carl Philipp Emanuel Bach, em seu Ensaio sobre a verdadeira maneira de tocar teclado ${ }^{5}$, de 1753-1762, no último capítulo da Parte II, intitulado Fantasia livre, assim caracteriza o pensamento harmônico a ser desenvolvido em uma peça desse gênero:

Nas fantasias em que há tempo suficiente para fazer-se ouvir, pode-se modular para tonalidades mais distantes. Aqui não se exigem sempre cadências formais; estas ocorrem no final e, em todo caso, uma vez no meio. [...] É um requinte da fantasia quando se finge que se vai modular para outra tonalidade através de uma cadência formal final e, então, toma-se uma outra direção. Este e outros artifícios inteligentes é que fazem com que uma fantasia seja boa. [...] 2009 [1753-1762], cap. $41, \S 8$, p. 442

A análise dos acordes e encadeamentos que conduzem o Rezitativ revelam a chegada, finalmente, do ponto culminante de um caminho harmônico planejado e construído, teleologicamente desde o c. 1. O caminho para o abandono da tonalidade de ré menor, que havia começado com um primeiro passo nos arpeggi de Ab, aqui se completa. Ainda que breve - inicia-se na entrada do c. 50 - o imprevisível ambiente harmônico que se instaura não permite que expectativas e previsões apareçam. São surpresas que se sucedem até percebermos que estamos no clímax da Fantasia, localizado exatamente na seção áurea, onde a liberdade já experimentada em termos métricos e melódicos, chega, finalmente, à harmonia.

\footnotetext{
${ }^{5}$ Versuch über die wahre Art das Clavier zu spielen.
} 


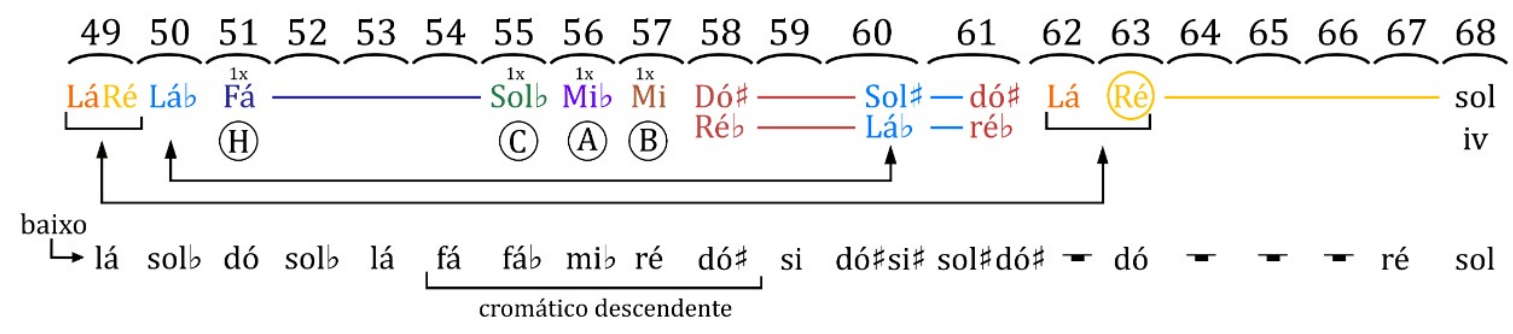

Figura 6: Rezitativ, identificação dos acordes dos c. 49 a 68.

Uma interpretação possível das relações harmônicas, expostas na Figura 6, parte da ideia de que a força do cromatismo tenha transformado, também, a base de sustentação do discurso harmônico da Fantasia, ou seja, os graus I, IV e V deslizariam um semitom abaixo. Uma modulação surpreendente de Ré para Réb (maior e/ou menor) pode ser admitida na concatenação desses intrincados relacionamentos acórdicos se tomarmos o acorde de Fá, III grau ${ }^{6}$, como acorde comum às duas tonalidades cromatizadas ${ }^{7}$. Este eixo representado pelo grau mediante entre as funções principais de uma tonalidade - Tônica e a Dominante - afasta os procedimentos de modulações padrão (realizadas pelo círculo das quintas) que levariam a tonalidades vizinhas ou próximas. Por estabelecer relações de terça - maior e menor, ascendente e descendente - com os graus I e V, o III grau permite que seus cromatismos sejam facilmente atingidos: Ré/Réb - Fá - Lá/Láb. Uma vez cromatizados, esses graus I e V engendrarão outros dois cromatismos: Sol/Solb (IV), Mi/Mib (V/V ou II).

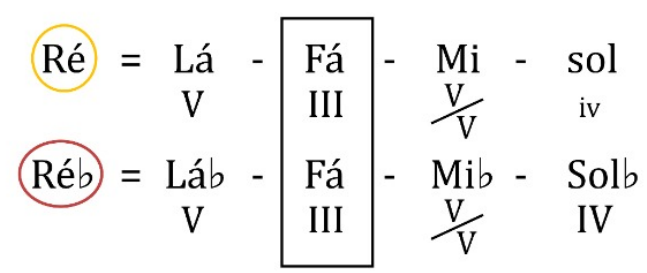

Figura 7: relação de eixo do III grau, Fá, com o I grau Ré e Réb.

\footnotetext{
${ }^{6}$ Em uma modulação comum, partindo de ré menor, Fá maior seria a nova tonalidade mais provável.

7 De acordo com a Harmonia Funcional, consideram-se os acordes diminutos como acordes de sétima ou de nona cujas notas Fundamentais foram omitidas. Embora as tétrades presentes no Rezitativ não sejam, necessariamente, ouvidas como funções Dominantes, optou-se por manter a nomeação funcional dos acordes, para facilitar sua identificação. Assim, o acorde de lá 7 dim é nomeado Fá, o de mi\# 7dim, de Dó\# e assim por diante.
} 
Além disso, se consideramos o acorde de Mi também como um acorde mediante - enarmonia de Fáb, vindo do cromatismo Fá/Fáb - podemos compreender as enarmonias entre a quinta Dó\#/Réb e Sol\#/Láb (c. 58, 60 e 61).

A disposição cromática dos nove acordes usados no Rezitativ atinge o âmbito de uma quinta aumentada, tendo o acorde de Fá, justamente, como centro:

\section{Lá-Láb-Sol-Solb-『R̃e-Mi-Mib-Ré-Réb.}

Os quatro acordes que aparecem uma única vez - Fá, Solb, Mib, Mi -, entre os c. 51 e 57, são a assinatura de Bach, transposta e retrogradada: Mi (B), Mib (A), Solb (C), Fá $(\mathrm{H})^{8}$.

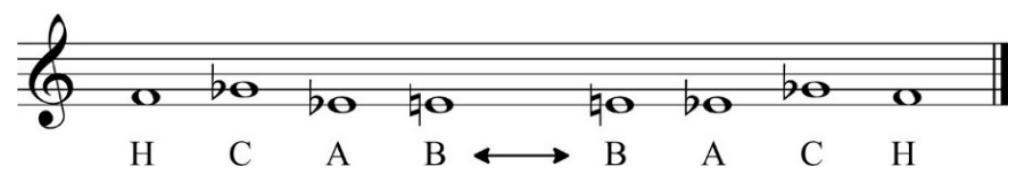

Figura 8: motivo BACH.

Embora todos os acordes sejam maiores e contenham sétimas ou nonas (excetuando-se os dos c. 61, dó\#/réb, e c. 68, sol), sua concentração e encadeamentos precipitados não permitem que suas funções de Dominantes sejam satisfatoriamente ouvidas em suas resoluções.

Partindo do movimento mais básico do idioma tonal, a cadência autêntica, ou seja, o movimento de quinta descendente que repousa em um centro, encontramos

1) no início, c. 49, Lá-Ré;

2) nos c. 60 e 61, Sol\#/Láb-dó\#/réb;

3) no fechamento, c. 62 e 63, quando os acordes do c. 49, Lá-Ré são repetidos, e seguem mais uma quinta para atingir o acorde de sol, (c. 68) confirmando a volta à tonalidade de ré menor por meio de sua subdominante.

Um movimento cadencial suspensivo acontece logo no c. 50, pois o acorde de Láb não leva de imediato a Réb, justamente o I grau cromatizado, que vai ser evitado e só vai ser ouvido no c. 58, confirmado em sua importância pela cadência autêntica que se segue nos c. 60 e 61.

\footnotetext{
${ }^{8}$ Na notação anglo-saxônica, a nota Lá corresponde à letra A, Sib a B, Dó a C e Si a H. O nome Bach é ouvido quando o motivo Sib (B)-Lá (Lá)-Dó (Dó)-Si (H) é executada.
} 


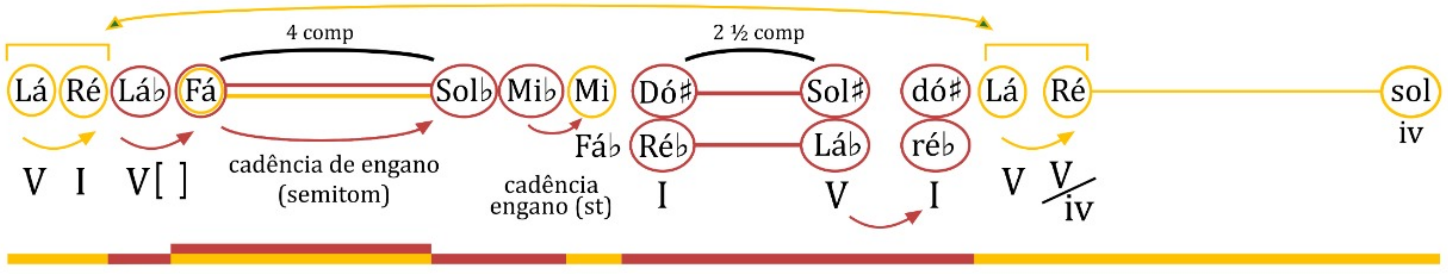

Figura 9: Rezitativ, c. 49 a 68, relações cadenciais entre acordes. Aqueles circulados em amarelos são diatônicos a Ré e, os em vermelho, a Réb. O acorde de Fá pertence às duas tonalidades.

As movimentações que se relacionam por semitom e que evocam o nome Bach podem ser vistas, harmonicamente, como cadências de engano, isto é, uma passagem de Dominante para uma função relativa ou antirrelativa do grau inicialmente almejado (V-VI).

c. 51 a 54: Fá, chegando a Solb (VI grau de sib) no c. 55;

c. 56: Mib chegando a Mi Fáb (VI grau de láb), no c. 57.

É interessante remarcar que os acordes que iniciam as cadências de engano Fá (c. 51) e Mib (c. 56), completam uma terça maior (dois tons inteiros) com a chegada do Dó\#/Réb, no c. 58, a resolução prometida pelo Láb do c. 50, e confirmam a tríade de Réb descendente, desde que o Láb apareceu pela primeira vez no c. 50.

\begin{tabular}{|c|c|c|c|}
\hline c. 50 & c. 51 a 54 & c.56 & c. 58 \\
\hline Láb & Fá & Mib & Réb \\
\hline
\end{tabular}

Os pilares da tonalidade da Fantasia - os acordes de Lá e Ré - e mais seus correspondentes cromáticos - Láb e Réb - estão em posições estratégicas espelhadas, início e fim do segmento em que ocorrem os cromatismos harmônicos, c. 49 e c. 62 e 63. 


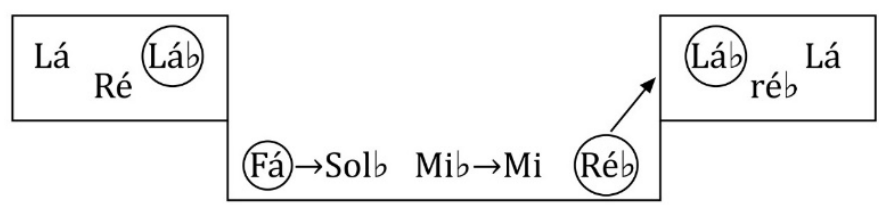

Figura 10: resumo e realce da estrutura que emoldura as cadências do Rezitativ, c.49 a 62.

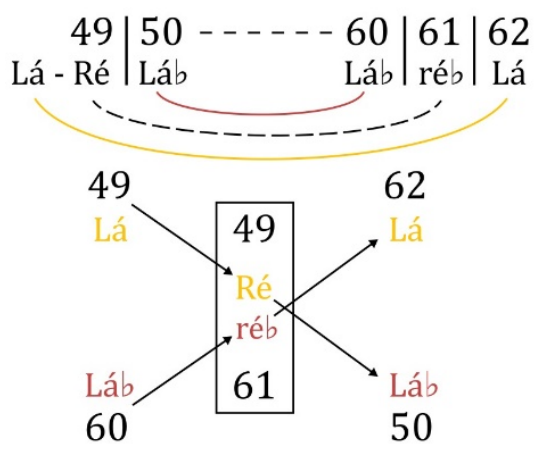

Figura 11: síntese da relação espelhada dos acordes Lá, Ré, Láb e Réb, c. 49 a 62.

\subsection{Parte C: c. 69 a 79}

Apenas onze compassos compõem essa parte final, que tem como função recuperar a tonalidade principal - ré - e convencer o ouvinte de que a fantasia, a inventividade e engenhosidade melódica métrica e sobretudo, harmônica, puderam ser desenvolvidas pois a promessa da volta da tonalidade da peça vai ser cumprida.

Dividida em duas pequenas subseções, de 6 e de 5 compassos, retoricamente sua importância é de uma "descompressão", uma volta gradativa das profundezas para a superfície.

A subseção compreendida entre os compassos 69 e 74 são uma síntese entre a assertividade harmônica do início, com cadências que recolocam o ouvido nas funções principais da tonalidade, recuperando as figurações melismáticas do Rezitativ sobre os acordes do acompanhamento secco.

A segunda, e final, subseção é a peroração, ou Coda, que leva todas as forças harmônicas, texturais, métricas e melódicas a seu ponto final.

Quando não se tem muito tempo para mostrar a própria arte no prelúdio, não se deve ir longe para tonalidades distantes, pois logo se vai ter que parar. Também não se deve abandonar, logo no início, a tonalidade principal e, no fim, retomá-la atrasada. No começo, a tonalidade principal deve dominar por certo tempo, para que se ouça com certeza o que se toca; antes do final deve-se também voltar a ela 
por um bom tempo, para que os ouvintes sejam preparados para o final da fantasia e para que a tonalidade principal impressione bem a memória (Bach 2009 [17531762], p. 440, § 6).

\subsubsection{Peroratio, c. 75 a 79}

A parte final da Fantasia se apresenta como uma engenhosa síntese dos componentes cromáticos presentes tanto na dimensão melódica quanto harmônica, confirmando e celebrando a tonalidade de ré/Ré por meio de um giro completo pelas dozes quintas do círculo. Começando no $3^{-}$tempo do c. 75, os acordes diminutos se encadeiam a cada tempo, obrigando-nos a enarmonizá-los, a partir do c. 76 para melhor compreendê-los.

Encastoando esse movimento pelo círculo, uma escala cromática completa, descendente, em colcheias, retoma o desenho fragmentado, também em colcheias descendente, e dos melismas, do Rezitativ e ainda restaura, para finalizar de forma mais veemente, a primeira escala cromática descendente ouvida na Fantasia, quando da apresentação da tonalidade, nos c. 10 e 11.

No penúltimo compasso, um gesto escalar sobre o acorde de sol menor (iv6), rememora as escalas dos c. 1 e 2.
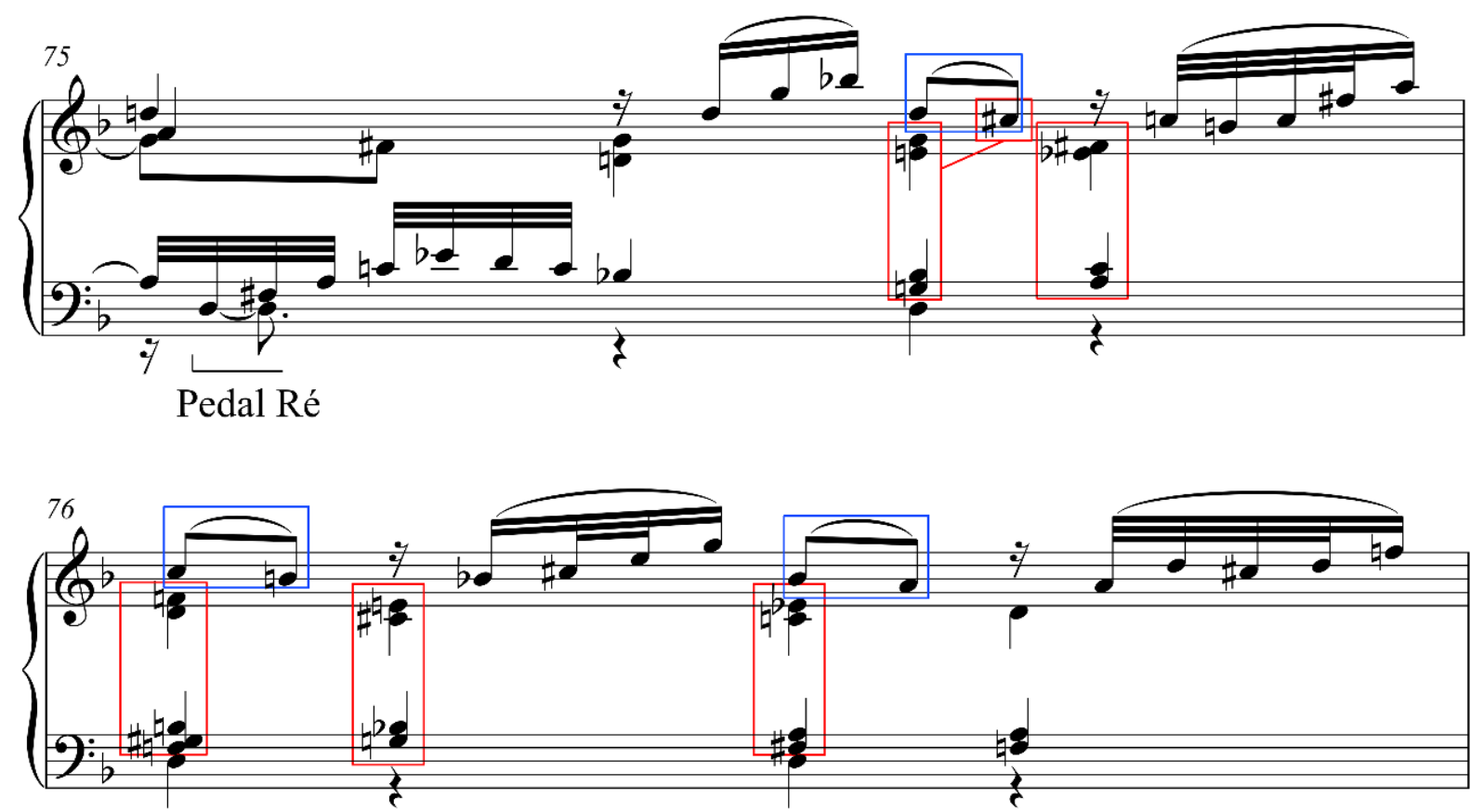

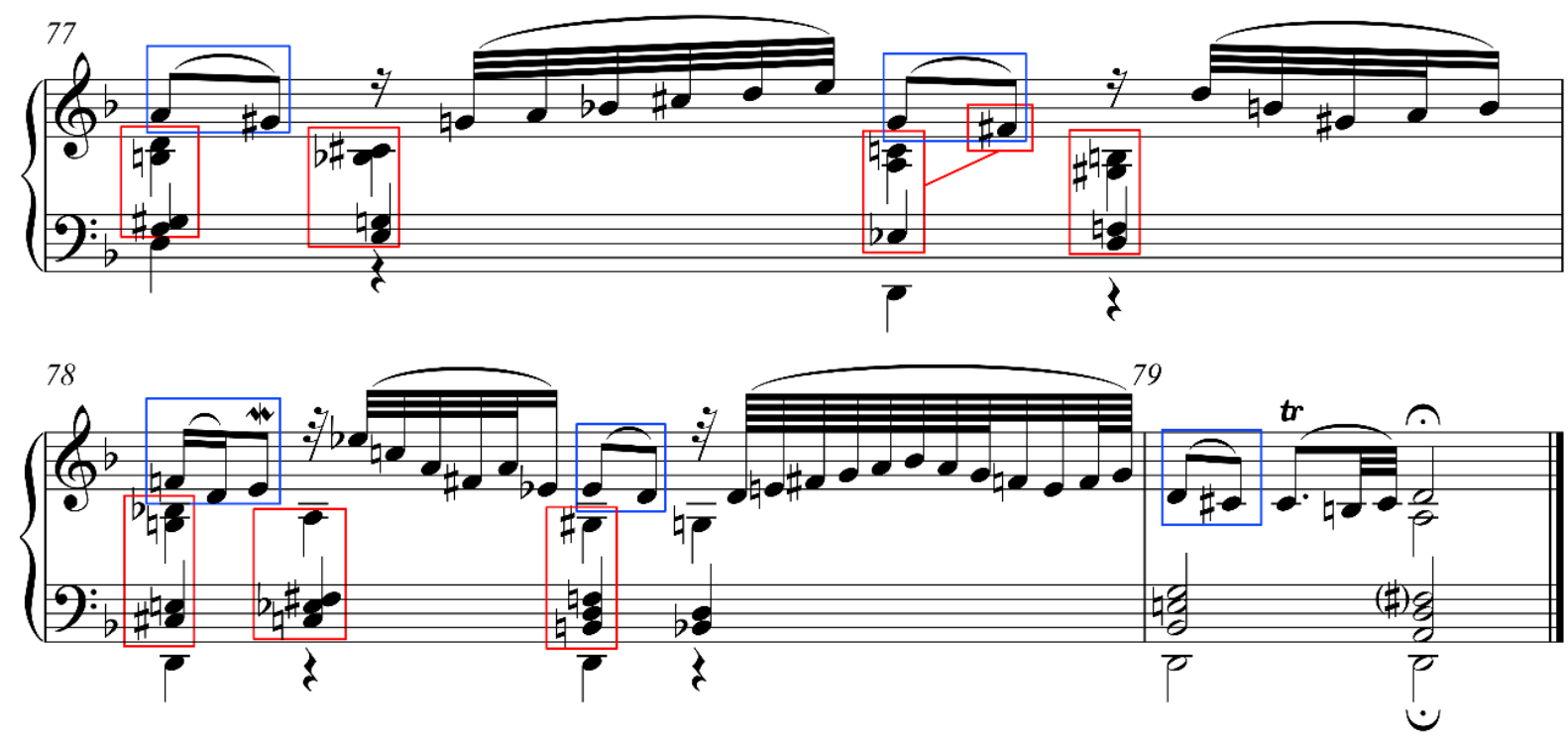

Exemplo 10: Peroratio, c. 75 a 79. Acordes diminutos no círculo das quintas e escala cromática descendente em colcheias.
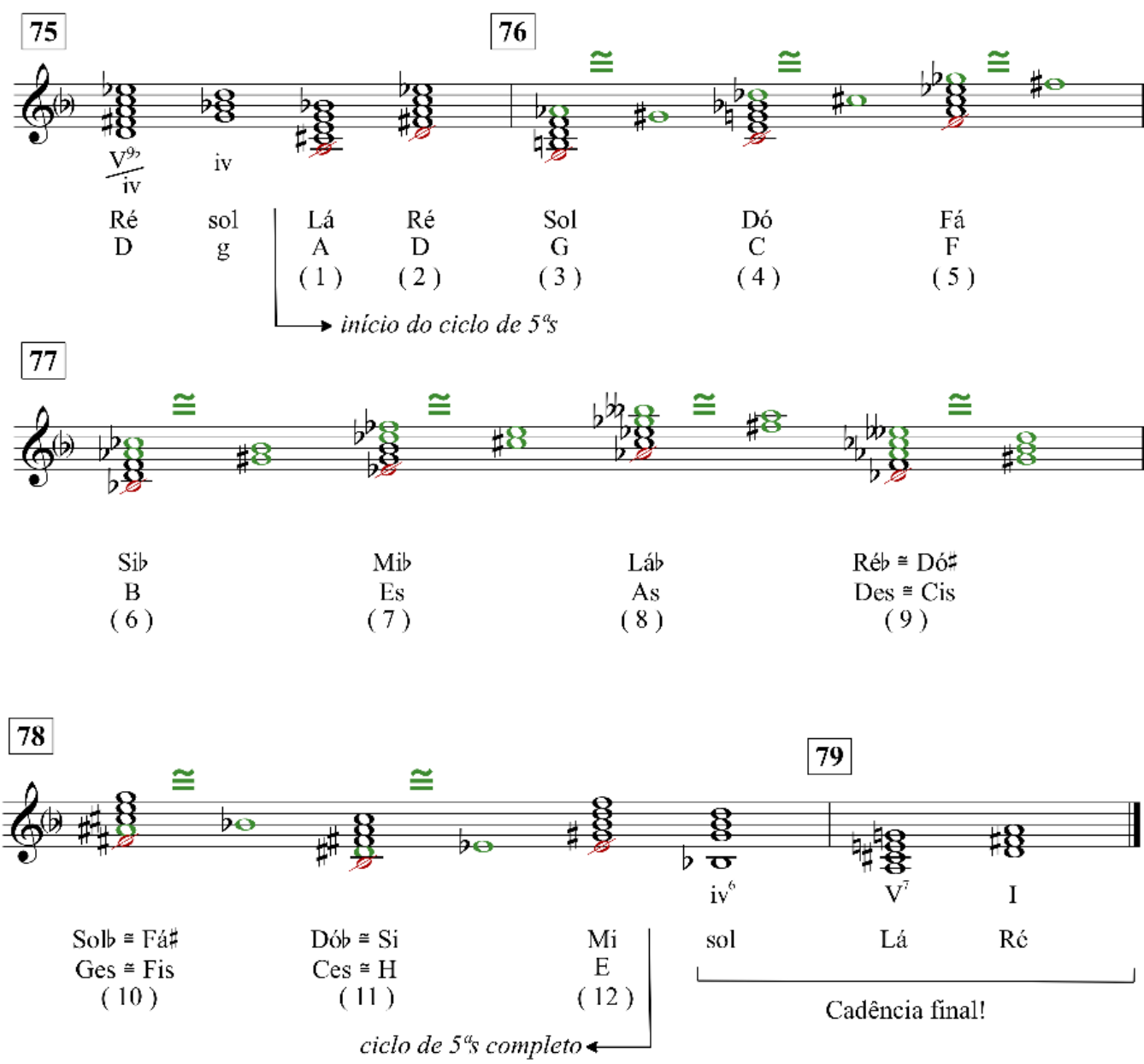

Figura 12: Peroratio, c. 75 a 79, resumo dos doze acordes diminutos com as enarmonizações. 


\section{Conclusões}

É característico de uma Fantasia ter uma estrutura formal seccionada, baseada no contraste e, muitas vezes, pensada como um mosaico que, para ser compreendido em sua unidade e inteireza, precisa de um afastamento do olhar.

A Fantasia Cromática apresenta essas segmentações que contêm esses contrastes harmônicos, texturais, métricos e melódicos suficientes para sua discriminação como unidades quase que autônomas de sentido, mas o olhar à distância nos revela uma estrutura regida pela proporção áurea em suas articulações mais significativas.

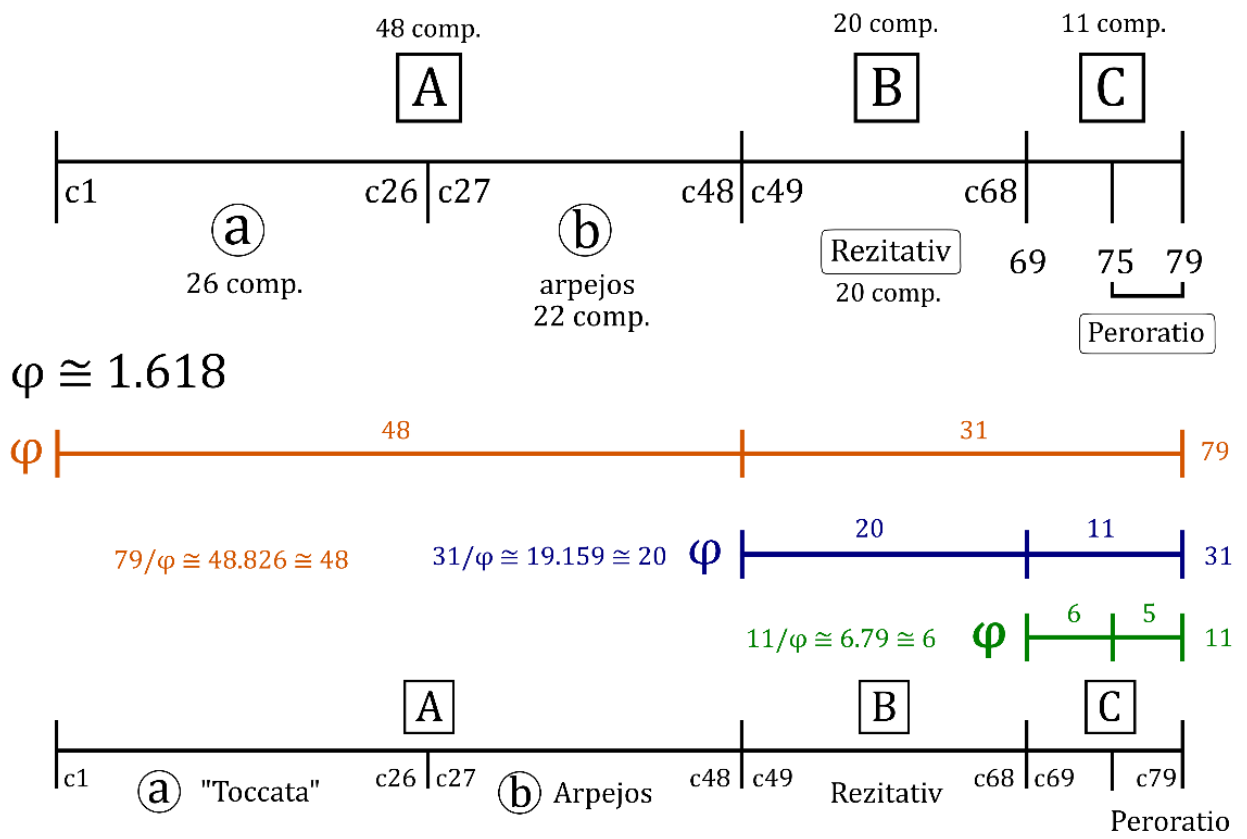

Figura 13: proporções áureas entre partes e seções.

Na forma global, o c. 49 - corte áureo do total dos 79 compassos - sinaliza o clímax da Fantasia, a entrada do Rezitativ, como já assinalado anteriormente.

A seção aqui nomeada $C$, que contém as subseções finais, em relação à seção $B$ (Rezitativ) e o Peroratio (subseção) em relação à seção $C$, replicam a proporção áurea com perfeição.

Seria este, mais um artifício inteligente, como disse C. P. E. Bach, entre tantos outros encontrados nessa pequena e magistral obra? 


\section{Referências Bibliográficas}

1. Bach, Carl Philipp Emanuel. 2009. Ensaio sobre a maneira correta de tocar teclado. Trad. Fernando Cazarini. Campinas: Editora da Unicamp.

2. Basso, Alberto. 1985. Jéan-Sebastien Bach. Vol. I e II. Trad. Hélène Pasquier. Paris: Fayard.

3. Brewer, Charles Everett. 2011. The Instrumental Music of Schmeltzer, Biber, Muffat and their Contemporaries. Burlington: Ashgate.

4. Collins, Paul. 2005. The Stylus Phantasticus and the Free Keyboard Music of the North German Baroque. London: Routledge.

5. Dahlhaus, Carl. 1956. Versuch über Bachs Harmonik. Bach Jahrbuch, n. 43, p. 7392.

6. Forkel, Johann Nikolaus. 2000 [1802]. Über Johann Sebastian Bachs Leben, Kunst und Kunstwerke. Berlin: Henschel.

7. Keller, Hermann. 1950. Die Klavierwerke Bachs: Beitrag zu ihrer Geschichte, Form, Deutung und Widergabe. Leipzig: C. F. Peters.

8. Kircher, Athanasius. 2017 [1650]. Musurgia Universalis. Disponível em $<$ https://www.hmt-leipzig.de/home/fachrichtungen/institut-fuermusikwissenschaft/forschung/musurgiauniversalis/volltextseite/content_710005/D_A07.pdf>. Acesso em: 5 jan. 2021.

9. Mattheson, Johann. 1999 [1739]. Der vollkommene Capellmeister: Neusatz des Textes und der Noten. Kassel: Bärenreiter.

10. Schleuning, Peter. 1969. "Dieser Fantasie ist einzig..." - Das Rezitativ in Bachs Chromatischer Fantasie und seine Bedeutung für die Ausbildung der freien Fantasie. In: Geck, Martin (Ed.). Bach-Interpretationen, Göttingen, p. 57-73.

11. _. 1990. "Bach's Chromatic Fantasy and Musical Sturm and Drang". In: Dirksen, Pieter (Ed.). The Harpsichord and its Repertoire: Proceedings of the International Harpsichord Symposium, Utrecht, p. 217-229.

12. Schulenberg, David. 2006. The Keyboard Music of J. S. Bach. 2a edição. New York: Routledge.

13. Steblin, Rita. 1996. A History of Key Characteristics in the Eighteenth and Nineteenth Centuries. New York: University of Rochester Press.

14. Wiemer, Wolfgang. 1988. Carl Philipp Emanuel Bachs Fantasie in c-moll - ein Lament auf den Todes Vaters? Bach Jahrbuch, n. 74, p. 163-177. 
15. Wolff, Christoph. 2000. Johann Sebastian Bach: The Learned Musician. New York: W. W. Norton \& Company. 